\title{
ON THE OCCURRENCE OF QUARTZOSE GRAVEL IN THE READING BEDS AT LANE END, BUCKS.
}

BY H. J. OSBORNE WHITE, F.G.S.

(Read June 8th, 1906.)

\begin{abstract}
$\triangle$ RECENT enlargement of one of the numerous excavations A for sand and clay that occur in the sides of the well-known Eocene outlier of Lane End, on the Chiltern Hills, has exposed, in the upper part of the Reading Beds, a series of coarse-textured deposits which are unlike any hitherto seen by me in that formation within the Tertiary Basin of London. The pit referred to is situated near the border of Ditchfield Common, at a point rather less than a hundred yards to the south-east of the parish church at Lane End, and close to the road leading from that village to Moor End Common and Frieth. It has been worked for many years, and sections formerly visible there were described by Mr. Whitaker in $1872, *$ and by me in 1899 ; the latter account being a very brief one embodied in a report of an excursion of the Geologists' Association.t These older sections, which were on the western side of the working and are now obscured by slips, showed the lowest beds of the London Clay (in a more or less reconstructed condition) resting upon light-coloured Reading Sands with thin beds of fine grey clay and a little ironstone. The newer exposures, which are on the eastern side, also show the Basement Bed of the London Clay, but the underlying sands are coarse and shingly, and contain lenticular bodies of currentbedded, subangular gravel of fine to medium texture.

The principal features of the section, as it appeared in January of the present year, are indicated in the accompanying sketch (Fig. I), and the beds there numbered in descending order are described below.
\end{abstract}

I. Soil and made ground, mostly of brown clay.

Feet.

( 2 (Basement-Bed). Evenly-stratified loamy sand with continuous seams of light, blue-grey, stiff clay, and of dull green, speckled, glauconitic sand; small concretions and laminæ of brown clay. ironstone.

At the base, a slightly undulate band (6 inches thick) of glauconitic, loamy sand containing flint pebbles (some of large size), and a few small quartz-pebbles $\quad \ldots \quad \ldots \quad \ldots \quad 5$ to 6

" "The Geology of the London Basin," Mem. Geol. Survey, vol, iv, p. 207. Republished in The Geology of London (1889), vol. 1, p. 183 .

$\uparrow$ Proc. Geol, Assoc., vol. xvi, part 5, p. 252.

Proc. Geol. Assoc., Vol. XIX, Part 9, I906.] 


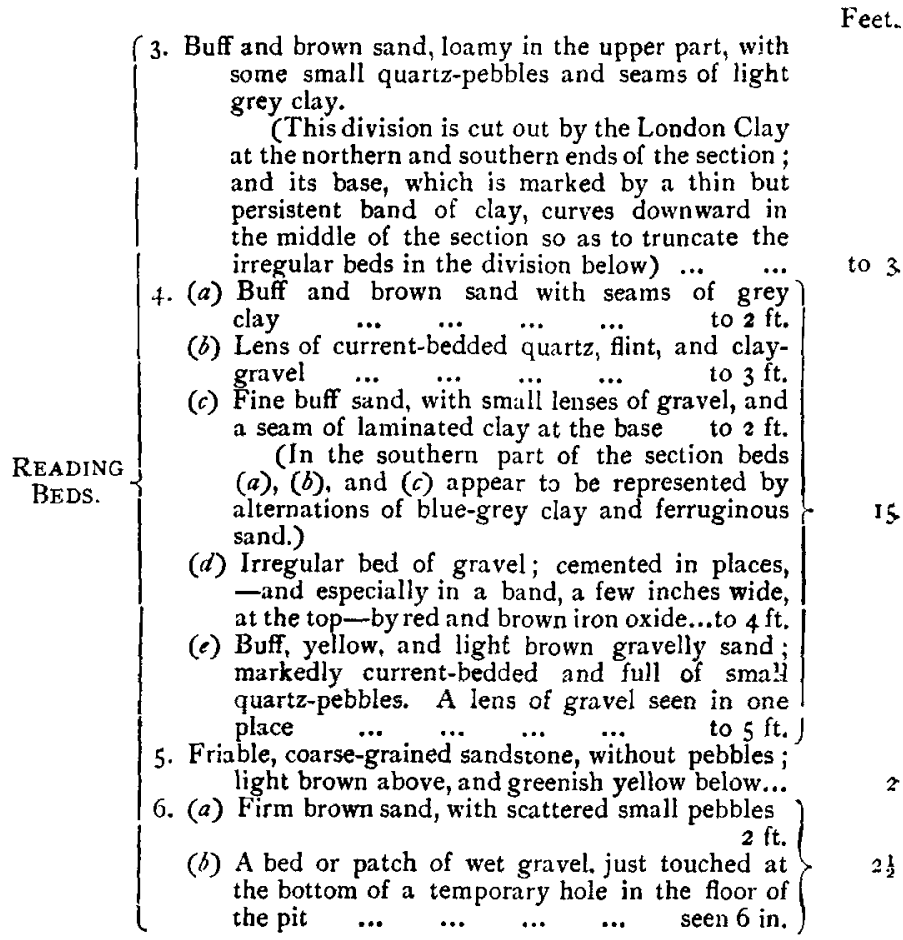

The coarser materials of the gravels and gravelly sands are:

Quarts-pebbles: White, yellowish, and pink; translucent and opaque. These are generally incompletely rounded, and range up to $I_{2} \frac{1}{2}$ in. in diameter. They form the bulk of the gravel.

Subangular fints: Mostly bleached a dull white, but commonly possessing a green tinge on the outside. Many are red within. A large proportion of the flints in this condition are fragments of tabular seams or veins ; and pieces of "carious " or "cavernous" nodules are abundant. Some of the less worn flints, which have formed part of solid nodules, fall into small splinters when removed from their matrix. Size : common up to 2 in. ; a few ranging up to 6 or 7 in. in diameter.

Flint nodules: Little worn. Mostly small and of globular and subcylindrical forms. Some are hollow and spongeous, and many have the dark green coating and corroded surface which characterise the nodules in the Reading "Bottom Bed." Small, club-shaped nodules, enclosing the lower portions of the stems of Coscinoporæ, are fairly common.

Flint pebbles: Black and grey, fairly common up to $I_{2} \frac{1}{2}$ in. in diameter, but greatly outnumbered by subangular flints. 


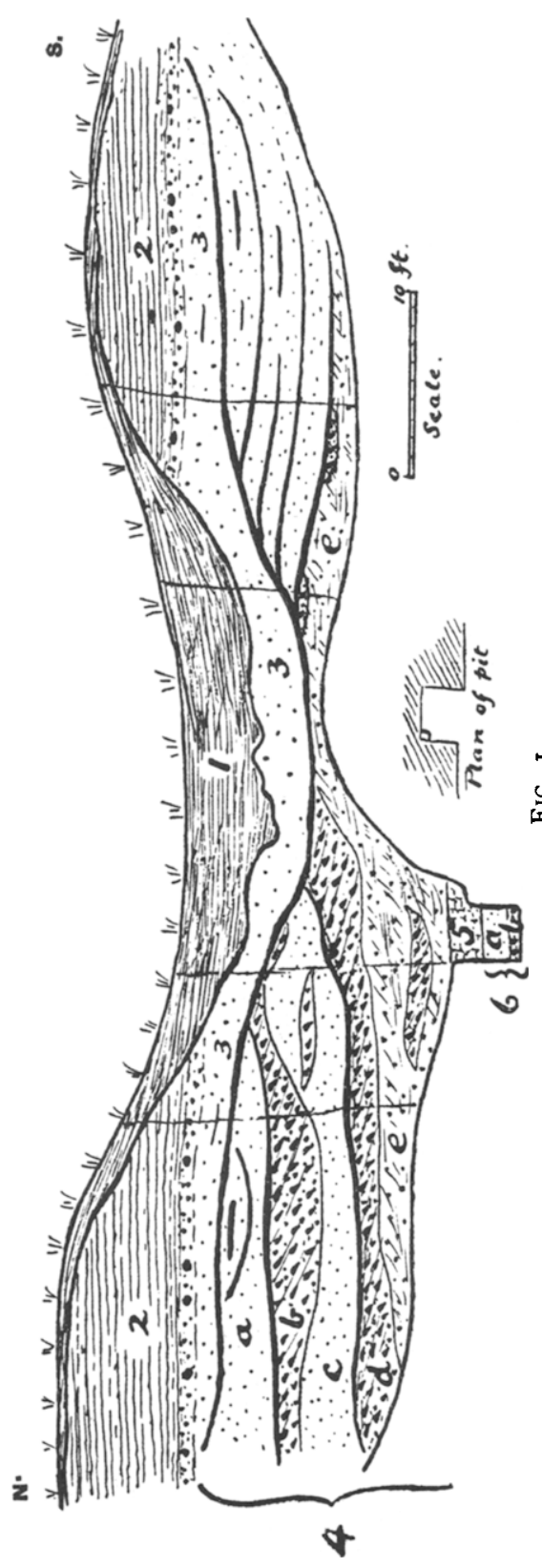

Clay: In sub. angular pieces and pebbles up to 4 in. in diameter. In some places these are so closely set as to give the gravel the appearance of a breccia.

Ironstone : I flaggy pieces and in concretions, enclosing pebbles of clay and other material.

Lydite : Black, polished, imperfectly rounded pebbles of chert or other siliceous rock ; often dull brown within. Mostly under $\frac{1}{2}$ in. in diameter.

Quartzite, or very compact, fine-grained sandstone, of light grey and light brown tints : in small ovate pebbles, to $\frac{5}{8}$ in. in diameter.

Sandstone : Brown, in pebbles to about $\frac{1}{2}$ in. in diameter.

Silicified Inoceramus-shell: Small pieces, abundant in places.

The interest of the above section centres in the beds and lenses of gravel and gravelly sand. Brecciate and conglomeratic beds, consisting of angular and rounded pieces of clay in a sandy matrix, are of common occurrence in the Reading series; subangular flints, also, 
have been noted in many places (though rarely in such quantities as here), but I can find no record of the occurrence of gravel abounding in pebbles of quartz and lydite in that series in any part of the London Basin.*

Recalling the confused state of some of the beds formerly visible on the western side of the excavation, I at first suspected the gravelly sands, with their uneven seams of clay, to be an elaborately deceitful sort of hill-wash or "trail," and their covering of London Clay to be one of those foundered masses so common on the flanks of the larger Eocene outliers. An examination of the section, however, revealed nothing to justify that interpretation, and much (in the way of structural detail) that was entirely opposed to it; and the small remaining doubts as to the Eocene age of the gravel-beds were soon dispelled by the discovery of similar deposits, associated with Reading Beds, in another part of the Lane End outlier.

By the Kiln near Muzwell Farm, at a spot about half-a-mile south-west of Lane End church and the section just described, there is an old and deep excavation in mottled clay, sands and loam. The beds here have been so much disturbed by the movements responsible for the trough-faulted syncline of Moor End Common, a little to the south, that their succession cannot be made out, with any certainty, in the present obscured state of the section. Coarse, gravelly, current-bedded sands, with lenses of ferruginous gravel, closely resembling those seen near the church, occur at the lower south-western end of the working, and might be inferred to pass beneath a considerable thickness of brown sand and mottled clay visible at higher levels close by ; but their apparently low position in the Reading Series here is almost certainly due to a strong south-westward dip, for there are some indications of the London Clay and its pebbly base in the disturbed ground which overlies them; and the occurrence of "very coarse" sand just beneath the basement bed of that formation at this place has been noted by Mr. Whitaker. $t$

The composition of the gravel is, qualitatively, the same as in the last section, but the small spheroidal flint nodules and fragments of tabular flint are more numerous, and the average size of the quartz-pebbles is rather greater.

There would seem, then, to be a considerable development of coarse sediment in the upper part of the Reading Series in this neighbourhood. It may be recalled that the lower beds of the formation in the Lane End outlier contain, at Boulter End, an exceptionally large shingle-bank which, where seen in section, consists of well-rounded and closely-packed pebbles of flint.

* Rounded and angular flints in light-coloured Reading clay and sand, with "a few small quartz pebbles," were seen by Mr. Whitaker, at Stoke Row, in Oxfordshire, Geol. Survey Memoit, on Sheet I3 (1862), p. 42 .

+ "Geology of the London Basin" (1872), p. 208, and "Geology of London" (188c), vol. 1, p. 184 ; see also Summary of Progress of the Geol. Survey for 1900, p. 122. 
Containing much subangular material, and lying, as they seem to do, in current-scoured hollows amid banks of finer sediment, the gravelly sands above described have a distinctly fluviatile, or estuarine, aspect. Their restriction, or apparent restriction, to an outlier situated in the outermost line of such residual masses on the northern slope of the London Basin* naturally suggests that their constituents were derived from land lying to the north, or north-west; and, having regard to the nature of the uncomformity between the Lower Eocene and Upper Cretaceous strata in this part of England, the character of some of these constituents renders it probable that such was actually the case.

The small spheroidal and subcylindrical spongeous flints, which are so abundant in these gravels, are especially characteristic of the Micraster cor-testudinarium-chalk of the Chilterns and Berkshire Downs, and bits of Inoceramus-shell, of the kind found here, are particularly plentiful at or about the same horizon. Near Lane End the Eocene rocks rest on the newer, M. cor-anguinum-beds, which have a local thickness of at least $\mathrm{r} 30 \mathrm{ft}$., but the general tendency shown by the Reading Beds to overstep the Chalk towards the north or north-west leads to the inference that lower sub-divisions of the latter formation came within reach of early Eacene erosion in the Midland area, north-west of the Chiltern Hills.

The pebbles of dark chert or lydite, which appear to be identical with those of the Portland Beds of the Vale of Aylesbury, also are suggestive of the northern derivation of the Lane End gravel. These little black stones, and pieces of quartz, are almost the only materials occurring in the Jurassic and Lower Cretaceous rocks of the Southern Midlands which would be likely to survive transportation, and long exposure to percolating water in a sand, in the condition of pebbles.

If these Reading gravels are the waste of a land which lay somewhere to the north, similar or even coarser deposits are likely to have occurred, and with increasing frequency, in that direction; and it may well be that the Lane End beds, which are in such marked contrast with the normal type of Reading sediment in the London Basin, present to us a facies of the formation which was a common one on the Chalk platform once extending beyond the present escarpment of the Chiltern Hills.

Now, having regard to the general south-eastward inclination and drainage of the rocks on this side of the London Basin, it can hardly be doubted that the superficial deposits on the Chilterns include some of the débris of the Chalk and newer strata which once overspread the area occupied by the Vale

\footnotetext{
- Since submitting this paper to the Secretary (in February, 1906) I have recognised remains of similar deposits in some blocks of very coarse irongtone-conglomerate occurring in the Clay-with.Flints at Queen Wood, and In loose drift associated with disturbed Reading loams at Russell's Water, in Oxfordshire. These places are tive to sis miles east of the Lane End outlier, and bigh up on the dip slope.
} 
of Aylesbury; and it is, therefore, of especial interest in the present connection to note the prevalence of quartzose driftgravel upon those hills. The gravel I refer to is the well-known variety of the Geological Survey's "Pebble Gravel," which the late Sir Joseph Prestwich regarded as the inland extension of the Pleistocene marine shingle of Westleton, near the coast of Suffolk.

The "IVestleton" hypothesis has not (to say the least) met with general acceptance; nor have the other suggestions relative to the age and origin of this upland drift, which have been brought forward since the publication of Prestwich's views in 1890 , called forth many expressions of approval. One of the chief difficulties - if not the chief difficulty--hitherto, has been to account for the abundant quartz-pebbles. Marine currents and rivers setting out from divers distant regions of quartzose rocks have been invoked, but the immediate source of this material has remained uncertain. Now, however, that such pebbles are known to occur, with a profusion unequalled in the drift gravel, in local beds of Reading age, this difficulty is overcome.

The Lower Eocene gravel of Lane End closely resembles the simpler type of Pebble Gravel found on the higher parts of the Chilterns. 'The drift gravel, it is true, is usually the coarser, and usually contains a larger proportion of flint pebbles; among its rarer constituents, also, there are a few rocks that I have not yet found in the Reading Beds : nevertheless, it is, on the whole, the sort of drift that would result from a blending of the débris of quartziferous Reading gravels with that of the ordinary Eocene pebble-beds ; and after a re-examination of many of the examples in South Oxon and Bucks I am much disposed to think that it has been formed in that manner.

Little novelty can be claimed for this view of the origin of the northern Pebble Gravel. A similar explanation was advanced, in 1900 , by Mr. Clement Reid,* who, however, did not, in his brief note, offer any suggestion as to the reason why materials rare in all the local Eocene Beds known to geologists at that date were common, and more than common, in the drift. Sir Henry Howarth, $t$ too, claimed a Reading Beds-origin for the Westleton shingle of Westletonand Southwold in 1895 , but he, also, left untouched that question of the relative frequency of certain rock-pebbles to which Sir Joseph Prestwich, Messrs. Monckton and Herries, Dr. Salter, and I have attached perhaps too much importance.

On the assumption that the simpler sort of quartzose Pebble

* Summary of Progress of the Geological Survey for $1899, \mathrm{p}$. I40. $\mathrm{Mr}$. Reid's note relates more directly to the gravels of the "Stanmore District" and Highgate, in Middlesex. At Stanmore he (or Mr. A. C. J. Cameron) fuund "rare fragments of Greensand-chert." Dr. Salter states that this material does not occur in the higher. less complex, Pebble Gravel of that neighbourhood, though it does so "plentifully " in the lower, Proc. Geol. A ssoc., vol. xix (1905), p. 25. Is Greensand-chert known from any bed indisputably of Eocene age around London?

$\dagger$ "On the Shingle Beds of Eastern East Anglia," Quart. Journ. Geol. Soc., vol. It, p. 497 . 
Gravel on the Chilterns is the wreck of coarse Eocene deposits formerly existing farther to the north, its wide range in altitude on the northern side of the London Basin, and its non-occurrence on the southern, are explicable without recourse to those extensive differential movements in recent times which are a corollary of the marine hypothesis of Prestwich. Originating on the higher part of the northern dip-slope, this drift has, we may suppose, travelled down the incline towards that somewhat ill. defined tract of uneven ground around London where we find its constituents mingling with the red quartzites and other materials from the Midlands, and the chert and ragstone from the Weald 